\title{
New biological and genetic classification and therapeutically relevant categories in childhood B-cell precursor acute
} lymphoblastic leukemia [version 1; peer review: 3 approved]

\author{
Jan Starý(Đ1,2, Jan Zuna1,2, Marketa Zaliova1,2 \\ ${ }^{1}$ Department of Pediatric Hematology and Oncology, Second Faculty of Medicine, Charles University and University Hospital Motol, \\ Prague, Czech Republic \\ ${ }^{2}$ Childhood Leukaemia Investigation Prague (CLIP), Prague, Czech Republic
}

V1 First published: 28 Sep 2018, 7(F1000 Faculty Rev):1569

https://doi.org/10.12688/f1000research.16074.1

Latest published: 28 Sep 2018, 7(F1000 Faculty Rev):1569

https://doi.org/10.12688/f1000research.16074.1

\begin{abstract}
Traditionally, genetic abnormalities detected by conventional karyotyping, fluorescence in situ hybridization, and polymerase chain reaction divided childhood B-cell precursor acute lymphoblastic leukemia (BCP-ALL) into well-established genetic subtypes. This genetic classification has been prognostically relevant and thus used for the risk stratification of therapy. Recently, the introduction of genome-wide approaches, including massive parallel sequencing methods (whole-genome, -exome, and -transcriptome sequencing), enabled extensive genomic studies which, together with gene expression profiling, largely expanded our understanding of leukemia pathogenesis and its heterogeneity. Novel BCP-ALL subtypes have been described. Exact identification of recurrent genetic alterations and their combinations facilitates more precise risk stratification of patients. Discovery of targetable lesions in subsets of patients enables the introduction of new treatment modalities into clinical practice and stimulates the transfer of modern methods from research laboratories to routine practice.
\end{abstract}

\section{Keywords}

acute lymphoblastic leukemia, children, massive parallel sequencing, new BCP-ALL subtypes

\section{Open Peer Review}

$\begin{array}{rrr}\text { Approval Status } & \\ 1 & 2 & 3\end{array}$

\section{version 1}

28 Sep 2018

Faculty Reviews are review articles written by the prestigious Members of Faculty Opinions. The articles are commissioned and peer reviewed before publication to ensure that the final, published version is comprehensive and accessible. The reviewers who approved the final version are listed with their names and affiliations.

\section{Nobutaka Kiyokawa, National Research Institute for Child Health and Development, Tokyo, Japan}

2. Ching-Hon Pui, University of Tennessee Health Science Center, Memphis, USA

\section{Stuart S. Winter, Children's Minnesota}

Research Institute, , Minneapolis, USA

Any comments on the article can be found at the end of the article. 
Corresponding author: Jan Starý (jan.stary@lfmotol.cuni.cz)

Author roles: Starý J: Writing - Original Draft Preparation; Zuna J: Writing - Review \& Editing; Zaliova M: Writing - Original Draft Preparation

Competing interests: No competing interests were disclosed.

Grant information: Institutional or infrastructure support were provided by the Ministry of Education, Youth and Sports of the Czech Republic (NPU I nr.LO1604), Charles University (UNCE 204012), the European Regional Development Fund - OP Prague (CZ.2.16/3.1.00/24022), and the National Center of Medical Genomics (CZ.02.1.01/0.0/0.0/16_013/0001634 - modernization of infrastructure and research of genetic variation in the population, OP RDE). This work was supported by the Ministry of Health, Czech Republic - conceptual development of research organization, Motol University Hospital, Prague, Czech Republic 00064203. The funders had no role in study design, data collection and analysis, decision to publish, or preparation of the manuscript.

Copyright: ( 2018 Starý J et al. This is an open access article distributed under the terms of the Creative Commons Attribution License, which permits unrestricted use, distribution, and reproduction in any medium, provided the original work is properly cited.

How to cite this article: Starý J, Zuna J and Zaliova M. New biological and genetic classification and therapeutically relevant categories in childhood B-cell precursor acute lymphoblastic leukemia [version 1; peer review: 3 approved] F1000Research 2018, 7 (F1000 Faculty Rev):1569 https://doi.org/10.12688/f1000research.16074.1

First published: 28 Sep 2018, 7(F1000 Faculty Rev):1569 https://doi.org/10.12688/f1000research.16074.1 


\section{Introduction}

Traditionally, B-cell precursor (BCP) acute lymphoblastic leukemia (ALL) has been classified into several distinct genetic subtypes defined by recurrent structural or numerical chromosomal alterations detected by cytogenetic methods (karyotyping and fluorescence in situ hybridization [FISH]), polymerase chain reaction (PCR), and flow cytometry (measurement of DNA content corresponding to ploidy) ${ }^{1}$. Six major genetic subtypes, altogether accounting for $70 \%$ to $75 \%$ of BCP-ALL, have been defined by high hyperdiploidy (51 to 67 chromosomes per leukemic cell), hypodiploidy (fewer than 45 chromosomes per leukemic cell), and ETV6-RUNX1, TCF3-PBX1, BCR-ABL1, and $K M T 2 A$ gene-involving fusions. These genetic aberrations have been characterized as first leukemogenic hits which are present in all cells comprising the leukemic clone, defining its key biological features as well as impacting the clinical character of respective BCP-ALL subtypes. Their identification has remained important until today for diagnosis specification and, in some of them, for risk classification and targeted therapy ${ }^{2}$.

Rapid progress of modern genetic techniques yielded important discoveries in various human diseases, including BCPALL. Genome-wide profiling using array-based comparative genomic hybridization, single-nucleotide polymorphism arrays, and massive parallel sequencing (MPS) of whole genomes, whole exomes, and whole transcriptomes (RNA sequencing, or RNA-seq) resulted in the identification of novel recurrent genetic aberrations and patterns. Among them, several prognostically significant and druggable aberrations which have started to be implemented into risk-stratification algorithms and targeted therapy have been described ${ }^{3}$. Moreover, together with genome-wide gene expression profiling on microarrays and by RNA-seq, modern genomic studies led to the identification of novel biologically and clinically relevant BCP-ALL subtypes $^{4}$. The so-called B-other ALL, a genetically and clinically heterogeneous subset of leukemias accounting for up to $30 \%$ of BCP-ALL (herein defined by negativity for all six above-mentioned classifying aberrations), was further dissected and better characterized. This review focuses on recent findings related to five novel BCP-ALL subtypes and selected clinically relevant genetic aberrations/patterns.

\section{New BCP-ALL subtypes}

Similar to the above-mentioned "classical" BCP-ALL subtypes, the five novel subtypes are distinguishable by their gene expression signatures; however, only three of them are also defined by the presence of a subtype-specific genetic aberration.

The first subtype, $B C R$ - $A B L 1$-like/Philadelphia chromosome-like (Ph-like) ALL (hereafter BCR-ABLI-like ALL), was already described in the "pre-MPS" era thanks to gene expression profiling on microarrays ${ }^{5,6}$. It is defined by a gene expression signature similar to that of $B C R-A B L 1$-positive ALL. This gene expression signature likely results from the activation of kinase signaling pathways, which, however, is not triggered by a single specific genetic aberration as in the case of $B C R-A B L 1$-positive ALL. On the contrary, a very wide spectrum of different genetic aberrations likely inducing this signature has been described in $B C R-A B L 1$-like $\mathrm{ALL}^{7-11}$. The aberrations affect genes encoding kinases (for example, JAK1, $J A K 2, J A K 3, A B L 1, A B L 2$, and TYK2), cytokine and growth factor receptors (for example, CRLF2, PDGFRB, EPOR, IL7R, CSF1R, NTRK3, and FLT3), and signaling mediators and regulators (KRAS, NRAS, BRAF, PTPN11, NF1, and SH2B3). These aberrations can be of various types, including both small-scale (deletions, insertions, substitutions, and complex mutations) and large-scale (chromosomal translocations and deletions) mutations which may generate fusion genes; of note, the majority of kinase/cytokine-receptor genes (JAK2, ABL1, and so on) can be fused to several different fusion partners. Such "kinase-signaling aberrations" can be found in $39 \%$ to $91 \%$ of $B C R$ - $A B L 1$-like ALL ${ }^{10,12,13}$; however, some of them also occur in B-other ALL not classified as BCR-ABL1-like ${ }^{9,14,15}$.

This ALL subtype was discovered independently by two studies. Although $B C R$-ABL1-like and Ph-like ALL, described by Dutch and American investigators, respectively, are now considered a single subtype, their definition is not fully consistent ${ }^{5,6}$. Some patients can be classified discordantly on the basis of classification approaches used by these two studies ${ }^{15}$. Several factors may contribute to this discrepancy, including methodological differences in gene expression data analysis, different composition of discovery cohorts (with respect to representation of various BCP-ALL subtypes, risk groups, and ethnicities), and the limited specificity of $B C R-A B L 1$ gene expression signature.

$B C R-A B L 1$-like ALL is the only novel subtype that was already added as a provisional entity into the 2016 update of World Health Organization (WHO) ALL classification ${ }^{16}$. It occurs in about $10 \%$ to $15 \%$ of pediatric BCP-ALL and accounts for about $15 \%$ to $35 \%$ of the B-other ALL group and its frequency increases with age. Both above-mentioned BCR-ABL1-like discovery studies reported its inferior outcome $e^{5,6}$. Although recent studies demonstrate that the overall survival of children with Ph-like ALL treated according to protocols employing minimal residual disease (MRD)-based risk stratification is not significantly inferior to that of non- $B C R-A B L 1$-like cases, such patients commonly exhibit inferior early response to therapy requiring treatment intensification ${ }^{13}$. Of note, it has been shown that outcome depends on the genomic context: the type of "kinase aberration" or presence of the IKZFI gene deletion (which has been recognized as an unfavorable prognostic factor in BCP-ALL as detailed below $)^{10,17}$.

The ETV6-RUNX1-like subtype was described within B-other ALL on the basis of tight co-clustering of some ETV6-RUNX1negative cases with ETV6-RUNX1-positive ALL according to gene expression profiling ${ }^{18}$. All cases belonging to this ALL subtype which have been described so far have a common genetic denominator: aberrations of the ETV6 gene ${ }^{18,19}$; however, these are not specific for the ETV6-RUNX1-like ALL and occur in other subtypes as well ${ }^{18,19}$. The ETV6 aberrations are usually deletions, but other gene-disrupting structural aberrations that may result in fusion genes were also described. Various alterations of IKZFI are also frequently detected within 
this subtype ${ }^{18,19}$. Biological proximity to ETV6-RUNX1-positive ALL is further supported by a similar expression pattern of two cell surface markers-CD27 and CD44-which can be measured by flow cytometry. Unlike the vast majority of other BCP-ALL subtypes, both ETV6-RUNX1-like and ETV6-RUNX1-positive ALL express CD27 but are negative or only partially or weakly positive for CD44 ${ }^{19,20}$. Such genotype-phenotype correlation is rather rare in BCP-ALL. Two studies describing this subtype so far indicate that it represents $5 \%$ to $12 \%$ of B-others and $1 \%$ to $3 \%$ of all BCP-ALL cases ${ }^{18,19}$. ETV6-RUNX1-like ALL does not appear to be associated with inferior prognosis; however, additional studies on larger cohorts are needed to reliably determine whether the prognosis of this novel subtype is as favorable as that of ETV6-RUNX1-positive ALL ${ }^{18,19}$.

DUX4-rearranged ALL was originally described as a B-other ALL subset with specific gene expression profile and frequent deletions of the ETS transcription factor gene $E R G^{21,22}$. Only recently, these leukemias have been characterized by a unique genetic aberration: rearrangements of the gene encoding transcription factor DUX4 $(D U X 4 r)^{18,23-25}$. These rearrangements are most frequently insertions of $D U X 4$ into the $I G H$ gene, resulting in the IGH-DUX4 fusion. The expression of DUX4, which is physiologically silenced in somatic tissues, is activated in DUX4r-ALL by its juxtaposition under the control of an ectopic regulatory element. The deletions of ERG can be detected in about $50 \%$ to $63 \%$ of cases $^{18,25}$. Although the rearrangement of DUX4 is an early, leukemia-initiating event ${ }^{24,25}$, the $E R G$ deletion is frequently a subclonal, thus secondary, aberration $^{26,27}$. It has been demonstrated that DUX4 binds to and deregulates the transcription of ERG in DUX4r-ALL; it induces the expression of alternative $E R G$ variant and perhaps also renders the $E R G$ gene prone to deletions ${ }^{25}$. Owing to the small size of the inserted chromosomal fragment ${ }^{18,24}$, the $I G H-D U X 4$ fusion (and other DUX4r) cannot be easily screened by FISH. Similarly, high variability of genomic breakpoints makes a potential fusion screening by PCR challenging. Thus, so far, this ALL subtype has been determined on the basis of its unique expression signature or presence of DUX4 fusion transcripts detected by RNA-seq ${ }^{18,23-25}$. DUX4r-ALL represents $4 \%$ to $8 \%$ of BCP-ALL and $15 \%$ to $30 \%$ of B-others. Before the DUX4r-ALL discovery, it had been shown that, despite the association with slow early treatment response and with prognostically unfavorable IKZFI deletions, ERG deletions were associated with favorable outcome ${ }^{26,27}$. Two recent studies reported favorable outcome also for DUX4r-ALL ${ }^{18,25}$. However, although the favorable outcome of BCP-ALL with $E R G$ deletions seems to derive from that of the DUX4r-ALL subtype, the outcome of DUX4r-ALL and potential prognostic impact of $E R G$ deletions within this subgroup should be further studied in larger and uniformly treated cohorts of patients. Interestingly, ERG deletions have been associated with an aberrant expression of CD2 and the tendency of leukemic blasts to switch immunophenotype from $\mathrm{BCP}$ to monocytoid at the beginning of treatment $t^{27,28}$. During this lineage switch, B lineage or progenitor markers such as CD19 and CD34 (or both) are lost, possibly hampering B-cell-oriented flow cytometric detection of minimal residual disease. Similar to the outcome, the likely association of lineage switch with the $D U X 4$ r-ALL subtype and impact of the ERG deletions on this association remain to be elucidated by future studies.

ALL with the ZNF384 gene-involving fusions (ZNF384r) represents another novel subtype of BCP-ALL ${ }^{23,24,29,30}$. The ZNF384 gene, encoding transcription factor zinc-finger protein 384 , can be fused to at least nine different partners (most frequently TCF3, EP300, or TAF15) in BCP-ALL. ZNF384r-ALL represents $1 \%$ to $5 \%$ of BCP-ALL and $5 \%$ to $10 \%$ of B-others. The unique gene expression signature of this ALL subtype is enriched for hematopoietic stem cell and immature myeloid lineage features and reflects upregulation of the JAK-STAT signaling pathway $^{30,31}$. ZNF384r-ALL also frequently displays a distinct immunophenotype compared with the majority of other BCPALL subtypes; the immunophenotypically distinct ZNF384rALL cases do not express (or only weakly express) CD10 marker but express myeloid markers CD13 or CD33 (or both) and may be even classified as mixed-phenotype acute leukemias on the basis of EGIL (European Group for the Immunological Characterization of Leukaemias) or WHO criteria ${ }^{30,32-34}$. The clinical features of ZNF384r-ALL may vary depending on ZNF384 fusion partner ${ }^{30}$. However, based on published studies reporting relatively small numbers of patients so far, ZNF384rALL does not appear to be a high-risk subtype in children ${ }^{30,34}$.

The last of the five novel ALL subtypes is defined by rearrangements of the $M E F 2 D$ gene $(M E F 2 D r)^{23,24,29}$. So far, at least six distinct $M E F 2 D$-involving fusion genes (with BCL9 gene being the most frequent fusion partner) have been described in this ALL subtype ${ }^{18,23,29}$. MEF2D encodes a transcription factor that plays a role in muscle and neuronal cell differentiation but is also expressed throughout B-cell differentiation ${ }^{35}$. The specific gene expression signature suggests a later differentiation stage of $M E F 2 D r-A L L$ compared with other BCP-ALL subtypes $^{29}$. Immunophenotyping by flow cytometry may also reveal specific features pointing toward this ALL subtype; $M E F 2 D$ r-ALL cells typically have relatively weak expression of $\mathrm{CD} 10$ and high expression of CD38 ${ }^{29}$. MEF2Dr-ALL represents $1 \%$ to $3 \%$ of childhood BCP-ALL and $2 \%$ to $5 \%$ of $\mathrm{B}$-others and is diagnosed more often in adolescents than in children. The outcome of MEF2Dr-ALL seems to be inferior to that of other ALL subtypes ${ }^{29,36}$. Alternative therapy employing histone deacetylase (HDAC) inhibitors which target HDAC9 (one of the $M E F 2 D r-A L L$ signature genes) and which were already successfully tested in vitro could potentially improve its outcome in the future ${ }^{29}$.

About $40 \%$ of B-other ALL cannot be classified into any of the five novel BCP-ALL subtypes. Various recurrent genomic aberrations can be found in patients belonging to this subset; some of them were already identified decades ago and others more recently. These include, for example, intrachromosomal amplification of chromosome $21 \quad(\mathrm{iAMP} 21)^{37}, \operatorname{dic}(9 ; 20)^{38}$, $I G H-M Y C^{39}$ and TCF3-HLF $F^{40}$ fusions, CRLF2 $2^{41,42}, N U T M 1^{29}$, or $P A X 5^{18,23,29}$ gene-involving fusions, and intragenic amplification of PAX5 (PAX5amp) $)^{43}$. Although some of them likely represent primary lesions and could be considered subtype-defining 
aberrations, others frequently represent secondary aberrations or co-occur with established primary lesions or across established BCP-ALL subtypes. Consequently, certain heterogeneity exists in the classification of BCP-ALL into genetic/ biological subtypes throughout the literature as well as in the definition of B-other ALL, which thus should always be explicitly described when used. One example of a potentially confusing situation is the classification of ALL with iAMP21. This ALL subset was added provisionally into the WHO 2016 ALL classification together with $B C R-A B L 1$-like $\mathrm{ALL}^{16}$, although it has been shown that these two ALL subsets partly overlap $^{15}$. Moreover, though it has been suggested to represent a primary lesion ${ }^{44}$, iAMP21, in a minor proportion of patients, co-occurs with other primary aberrations such as $B C R-A B L 1$ or ETV6-RUNX1 fusions. Similarly, CRLF2 rearrangement (CRLF2r) that is sometimes used to define the subset of patients within B-other $\mathrm{ALL}^{45}$ is frequently a secondary aberration ${ }^{46}$ and also occurs across several BCP-ALL subtypes (BCR-ABL1positive ALL, $B C R$ - $A B L 1$-like ALL, and hyperdiploid and hypodiploid ALL) $)^{11,41,47,48}$. Nevertheless, identification of these aberrations is clinically relevant, as some of them were proven to have unfavorable prognostic impact and thus influence risk stratification and therapy (for example, iAMP2 $1^{49,50}$ and $T C F 3-H L F^{51}$ ) whereas in others the suggested prognostic impact needs further validation (for example, $P A X 5 \mathrm{amp}^{52}$ ). Importantly, various aberrations may qualify patients for a targeted therapy (for example, CRLF2r) as further discussed below.

\section{New therapeutically relevant aberrations/categories}

A variety of novel druggable lesions, especially of kinaseactivating aberrations, have been described thanks to the introduction of MPS in recent years. As already mentioned above, the kinase-activating lesions are highly enriched in the $B C R$ $A B L 1$-like ALL subtype ${ }^{9,10,15}$. A large proportion of these aberrations can be assigned into one of two functional classes according to the affected signaling pathway: JAK/STAT class and ABL class ${ }^{10,17,53}$. The more frequent JAK/STAT class aberrations comprise aberrations affecting CRLF2, JAK1, JAK2, $J A K 3, E P O R, I L 7 R$, and $S H 2 B 3$ genes and can be targeted by the JAK inhibitor ruxolitinib. The most frequently affected $C R L F 2$ gene encodes one of two subunits of heterodimeric receptor for thymic stromal lymphopoietin. In addition to constitutively activating $\mathrm{F} 232 \mathrm{C}$ mutation $^{54,55}$, two types of CRLF2-involving fusion have been described: IGH-CRLF2, which results from interchromosomal translocation, and P2RY8-CRLF2, which is caused by deletion in the PAR1 region on gonosomes ${ }^{41,42}$. Both fusions lead to an overexpression of intact CRLF2 protein on the cell surface, which can be reliably detected by flow cytometry ${ }^{42,56}$. Thus, with the use of anti-CRLF2 antibody, CRLF2r-positive patients (who represent up to $17 \%$ of B-other $\mathrm{ALL}^{18}$ and who might be considered for targeted therapy by ruxolitinib) can be easily identified during diagnostic immunophenotyping. The second class of kinase-activating aberrations, the ABL class, comprise ABL1, ABL2, PDGFRB, PDGFRA, and $C S F 1 R$ gene-involving fusions. These aberrations can be inhibited by tyrosine-kinase inhibitors (TKIs) such as imatinib or dasatinib $^{10}$, both of which have already become an inherent component of the treatment of pediatric $B C R-A B L 1$-positive
$\mathrm{ALL}^{57}$. Aberration of additional receptor and non-receptor kinase genes (for example, NTRK3,TYK2, DGKH, and PTK2B) that do not belong to these two classes but that at least in some cases can be targeted by known inhibitors can be also detected, though rarely, in $B C R$ - $A B L 1$-like $\mathrm{ALL}^{10}$. In addition to these lesions associated with the $B C R-A B L 1$-like phenotype, aberrations resulting in the activation of the Ras/Raf/MAPK pathway (hereafter, Ras pathway) occur frequently across various BCP-ALL subtypes ${ }^{58-62}$. Activating point mutations of the KRAS and NRAS genes are the most abundant, whereas mutations of the FLT3, PTPN11, NF1, and BRAF genes occur less frequently. It has been shown that leukemic cells with Ras pathway mutations are sensitive to MEK inhibitors in vitro ${ }^{63,64}$.

Sensitivity tests performed in vitro and in patient-derived xenografts provided a solid rationale for prospective clinical testing of TKIs in BCP-ALL with novel kinase-activating aberrations ${ }^{17,53}$. However, a relatively limited number of such children already treated by TKIs have been reported in the literature so far ${ }^{10,14,65-73}$. Although several case reports described good response to ABL class inhibitors in patients with $A B L 1 / A B L 2$ or $P D G F R B$ gene-involving fusions ${ }^{10,66,67,70-72,74}$ and overall results are generally encouraging, in some patients the TKI-involving treatment failed to induce long-term remission. This can be at least partially due to the fact that TKIs were added to treatment only upon diagnosis of disease resistance/relapse. Additionally, cases of secondary TKI resistance caused by mutations in targeted kinase (that is, by the most common mechanism of resistance known in $B C R$ $A B L 1$-positive leukemias) have already been described ${ }^{75,76}$. The first clinical trials have been initiated recently which use frontline TKIs added to chemotherapy backbone for selected groups of patients with kinase-activating lesions (ClinicalTrials.gov Identifier: NCT03117751 sponsored by St. Jude Children's Research Hospital, Memphis, TN, USA; ClinicalTrials.gov Identifier: NCT02420717 sponsored by MD Anderson Cancer Center, Houston, TX, USA; ClinicalTrials.gov Identifier: NCT02883049 sponsored by the National Cancer Institute, Rockville, MD, USA; and ClinicalTrials.gov Identifier: NCT03020030 sponsored by the Dana-Farber Cancer Institute, Boston, MA, USA). Importantly, several clinical and biological aspects should be considered in the strategies for prospective TKI testing in newly diagnosed BCP-ALL. It should be discussed carefully whether it is justified to use TKIs in all children with any targetable kinaseactivating aberration, whether they should be used only in children harboring a lesion unambiguously associated with unfavorable outcome (similar to $B C R-A B L 1$ fusion), or whether the TKIs should be reserved for patients with worse early response to treatment or with resistant disease, where the potential benefits most likely outweigh an increase of treatment toxicity $^{77}$. Moreover, it is important to consider that while some of the kinase and cytokine-receptor gene alterations are supposed to represent founding lesions present in all leukemic cells and essential for their survival ${ }^{10,78-80}$, some aberrations may be either founding or secondary lesions (for example, $C R L F 2$ r) and others are typically secondary subclonal lesions (for example, JAK/RAS gene mutations), possibly without a 
resistance- or relapse-driving role, thus probably representing less-suitable therapeutic targets ${ }^{46,81}$.

Deletions of the IKZFI gene (IKZFIdel) encoding lymphoid transcription factor Ikaros occur in $9 \%$ to $15 \%$ of BCP-ALL and more frequently in B-other, $B C R$ - $A B L 1$-positive, and hypodiploid ALL compared with remaining subtypes ${ }^{17,43,59,82,83}$. In 2009 , the $I K Z F 1$ del was associated with poor outcome ${ }^{6}$; subsequently, multiple studies confirmed its negative prognostic impact in $\mathrm{BCP}-\mathrm{ALL}^{82-92}$. These findings stimulated the incorporation of $I K Z F I$ del into risk-stratification algorithms as a factor qualifying for treatment intensification in some ALL trials (ClinicalTrials.gov Identifier: NCT03020030 sponsored by the Dana-Farber Cancer Institute and ClinicalTrials.gov Identifier: NCT02716233 sponsored by Assistance Publique - Hôpitaux de Paris, France). However, partially discrepant findings of individual studies showed that the prognostic impact of IKZFIdel (its strength and independence on other known risk factors) depends on, for example, risk-stratification algorithms, applied therapy, and early treatment response. Moreover, it was revealed that it is modified by the presence of other genetic lesions. First, it was shown that deletions in the $E R G$ gene $(E R G$ del $)$ attenuate the negative prognostic impact of $I K Z F 1 \mathrm{del}^{26,27}$; a subsequent study demonstrated that other recurrent deletions may have the opposite effect ${ }^{93}$. These findings led to the establishment of the IKZFIplus category ${ }^{93}$, defined as $I K Z F I$ del with concurrent deletion of $P A X 5$ or $C D K N 2 A$ or $C D K N 2 B$ genes or deletion of PAR1 region (resulting in $P 2 R Y 8-C R L F 2$ fusion gene) or with a combination of these, in the absence of $E R G$ del. The IKZFIplus genomic pattern occurs in $6 \%$ of BCP-ALL, is associated with inferior outcome in patients with detectable minimal residual disease at the end of induction treatment, and will be used for risk stratification in the upcoming AIEOP-BFM (Associazione Italiana di Ematologia ed Oncologia Pediatrica-Berlin-Frankfurt-Münster) ALL trial ${ }^{93}$. IKZFlplus occurs predominantly in B-other ALL; although we can assume its enrichment in subtypes with higher frequency of $I K Z F I$ del, such as $B C R$ - $A B L 1$-like ALL, its distribution and prognostic role across novel BCP-ALL subtypes remain to be elucidated by future studies. These studies could also help to clarify the strong association between $I K Z F 1$ plus prognostic value and the early therapy response.

\section{Conclusions}

Herein, we briefly reviewed some of the most important recent findings in pediatric BCP-ALL, demonstrating that the use of modern high-throughput technologies not only advanced our insight into the genetics and biology of BCP-ALL but also paved the way for novel treatment options. However, with growing knowledge, we have begun to recognize more extensively that the significance (for example, clinical relevance) of individual factors may vary substantially depending on additional genetic/biological contexts. Enormous effort will still be needed to further improve our understanding of the considerably complex relationships between genetic/biological and clinical aspects of BCP-ALL and to better translate this knowledge into further improvements in patient outcome.

\section{Abbreviations}

ALL, acute lymphoblastic leukemia; BCP, B-cell precursor; FISH, fluorescence in situ hybridization; MPS, massive parallel sequencing; PCR, polymerase chain reaction; Ph-like, Philadelphia chromosome-like; RNA-seq, RNA sequencing; TKI, tyrosine-kinase inhibitor; WHO, World Health Organization

\section{Grant information}

Institutional or infrastructure support were provided by the Ministry of Education, Youth and Sports of the Czech Republic (NPU I nr.LO1604), Charles University (UNCE 204012), the European Regional Development Fund - OP Prague (CZ.2.16/3.1.00/24022), and the National Center of Medical Genomics (CZ.02.1.01/0.0/0.0/16_013/0001634 - modernization of infrastructure and research of genetic variation in the population, OP RDE). This work was supported by the Ministry of Health, Czech Republic - conceptual development of research organization, Motol University Hospital, Prague, Czech Republic 00064203.

The funders had no role in study design, data collection and analysis, decision to publish, or preparation of the manuscript.
1. Pui $\mathrm{CH}$, Relling MV, Downing JR: Acute lymphoblastic leukemia. $N$ Engl J Med. 2004; 350(15): 1535-48

PubMed Abstract | Publisher Full Text

2. Harrison $\mathrm{CJ}$, Haas $\mathrm{O}$, Harbott $\mathrm{J}$, et al: Detection of prognostically relevant genetic abnormalities in childhood B-cell precursor acute lymphoblastic leukaemia: recommendations from the Biology and Diagnosis Committee of the International Berlin-Frankfürt-Münster study group. Br J Haematol. 2010; 151(2): 132-42.

PubMed Abstract | Publisher Full Text

3. F lacobucci I, Mullighan CG: Genetic Basis of Acute Lymphoblastic Leukemia. J Clin Oncol. 2017; 35(9): 975-83.

PubMed Abstract | Publisher Full Text | Free Full Text | F1000 Recommendation

4. $\quad \mathrm{F}$ Lilljebjörn $\mathrm{H}$, Fioretos $\mathrm{T}$ : New oncogenic subtypes in pediatric B-cell precursor acute lymphoblastic leukemia. Blood. 2017; 130(12): 1395-401. PubMed Abstract | Publisher Full Text | F1000 Recommendation
5. Den Boer ML, van Slegtenhorst M, De Menezes RX, et al:: A subtype of childhood acute lymphoblastic leukaemia with poor treatment outcome: a genome-wide classification study. Lancet Oncol. 2009; 10(2): 125-34. PubMed Abstract | Publisher Full Text | Free Full Text

6. $\quad F$ Mullighan CG, Su X, Zhang J, et al.: Deletion of IKZF1 and prognosis in acute lymphoblastic leukemia. $N$ Engl J Med. 2009; 360(5): 470-80. PubMed Abstract | Publisher Full Text | Free Full Text | F1000 Recommendation

7. Boer JM, Steeghs EM, Marchante JR, et al:: Tyrosine kinase fusion genes in pediatric BCR-ABL1-like acute lymphoblastic leukemia. Oncotarget. 2017; 8(3) 4618-28.

PubMed Abstract | Publisher Full Text | Free Full Text

8. $\mathrm{F}$ Imamura $\mathrm{T}$, Kiyokawa $\mathrm{N}$, Kato M, et al: Characterization of pediatric Philadelphia-negative B-cell precursor acute lymphoblastic leukemia with kinase fusions in Japan. Blood Cancer J. 2016; 6: e419. PubMed Abstract | Publisher Full Text | Free Full Text | F1000 Recommendation 
9. F Reshmi SC, Harvey RC, Roberts KG, et al.: Targetable kinase gene fusions in high-risk B-ALL: a study from the Children's Oncology Group. Blood. 2017; 129(25): 3352-61.

PubMed Abstract | Publisher Full Text | Free Full Text | F1000 Recommendation

10. F Roberts KG, Li Y, Payne-Turner D, et al:: Targetable kinase-activating lesions in Ph-like acute lymphoblastic leukemia. N Engl J Med. 2014; 371(11): 1005-15. PubMed Abstract | Publisher Full Text | Free Full Text | F1000 Recommendation

11. F Roberts KG, Morin RD, Zhang J, et al:: Genetic alterations activating kinase and cytokine receptor signaling in high-risk acute lymphoblastic leukemia. Cancer Cell. 2012; 22(2): 153-66.

PubMed Abstract | Publisher Full Text | Free Full Text | F1000 Recommendation

12. F Roberts KG, Reshmi SC, Harvey RC, et al.: Genomic and outcome analyses of Ph-like ALL in NCl standard-risk patients: a report from the Children's Oncology Group. Blood. 2018; 132(8): 815-24.

PubMed Abstract | Publisher Full Text | Free Full Text | F1000 Recommendation

13. F Roberts KG, Pei D, Campana D, et al:: Outcomes of children with BCR-ABL1like acute lymphoblastic leukemia treated with risk-directed therapy based on the levels of minimal residual disease. J Clin Oncol. 2014; 32(27): 3012-20. PubMed Abstract | Publisher Full Text | Free Full Text | F1000 Recommendation

14. Zaliova M, Moorman AV, Cazzaniga G, et al:: Characterization of leukemias with ETV6-ABL1 fusion. Haematologica. 2016; 101(9): 1082-93.

PubMed Abstract | Publisher Full Text | Free Full Text

15. Boer JM, Marchante JR, Evans WE, et al: BCR-ABL1-like cases in pediatric acute lymphoblastic leukemia: a comparison between DCOG/Erasmus MC and COG/St. Jude signatures. Haematologica. 2015; 100(9): e354-7. PubMed Abstract | Publisher Full Text | Free Full Text

16. Arber DA, Orazi A, Hasseriian R, et al:: The $\mathbf{2 0 1 6}$ revision to the World Health Organization classification of myeloid neoplasms and acute leukemia. Blood. 2016; 127(20): 2391-405 PubMed Abstract | Publisher Full Text

17. F Roberts KG, Yang YL, Payne-Turner D, et al.: Oncogenic role and therapeutic targeting of ABL-class and JAK-STAT activating kinase alterations in Ph-like ALL. Blood Adv. 2017; 1(20): 1657-71. PubMed Abstract | Free Full Text | F1000 Recommendation

18. F Lilljebjörn $\mathrm{H}$, Henningsson R, Hyrenius-Wittsten $\mathrm{A}$, et al:: Identification of ETV6-RUNX1-like and DUX4-rearranged subtypes in paediatric B-cell precursor acute lymphoblastic leukaemia. Nat Commun. 2016; 7: 11790. PubMed Abstract | Publisher Full Text | Free Full Text | F1000 Recommendation

19. Zaliova M, Kotrova M, Bresolin S, et al:: ETV6/RUNX1-like acute lymphoblastic leukemia: A novel B-cell precursor leukemia subtype associated with the CD27/CD44 immunophenotype. Genes Chromosomes Cancer. 2017; 56(8): 608-16.

PubMed Abstract | Publisher Full Text

20. Vaskova M, Mejstrikova E, Kalina T, et al:: Transfer of genomics information to flow cytometry: expression of CD27 and CD44 discriminates subtypes of acute lymphoblastic leukemia. Leukemia. 2005; 19(5): 876-8.

PubMed Abstract | Publisher Full Text

21. Mullighan CG, Miller CBS, Su X, et al:: ERG Deletions Define a Novel Subtype of B-Progenitor Acute Lymphoblastic Leukemia. Blood. (ASH Annual Meeting Abstracts). 2007; 110(11): 691

Reference Source

22. Yeoh EJ, Ross ME, Shurtleff SA, et al:: Classification, subtype discovery, and prediction of outcome in pediatric acute lymphoblastic leukemia by gene expression profiling. Cancer Cell. 2002; 1(2): 133-43. PubMed Abstract | Publisher Full Text

23. F Liu YF, Wang BY, Zhang WN, et al:: Genomic Profiling of Adult and Pediatric B-cell Acute Lymphoblastic Leukemia. EBioMedicine. 2016; 8: 173-83. PubMed Abstract | Publisher Full Text | Free Full Text | F1000 Recommendation

24. F Yasuda T, Tsuzuki S, Kawazu M, et al.: Recurrent DUX4 fusions in B cell acute lymphoblastic leukemia of adolescents and young adults. Nat Genet. 2016; 48(5): 569-74

PubMed Abstract | Publisher Full Text | F1000 Recommendation

25. $\mathrm{F}$ Zhang J, McCastlain $\mathrm{K}$, Yoshihara $\mathrm{H}$, et al.: Deregulation of DUX4 and ERG in acute lymphoblastic leukemia. Nat Genet. 2016; 48(12): 1481-9. PubMed Abstract | Publisher Full Text | Free Full Text | F1000 Recommendation

26. F Clappier E, Auclerc MF, Rapion J, et al:: An intragenic ERG deletion is a marker of an oncogenic subtype of B-cell precursor acute lymphoblastic leukemia with a favorable outcome despite frequent IKZF1 deletions. Leukemia. 2014; 28(1): 70-7.

PubMed Abstract | Publisher Full Text | F1000 Recommendation

27. Zaliova $\mathrm{M}$, Zimmermannova $\mathrm{O}$, Dörge $\mathrm{P}$, et al.: ERG deletion is associated with CD2 and attenuates the negative impact of IKZF1 deletion in childhood acute lymphoblastic leukemia. Leukemia. 2014; 28(1): 182-5.

PubMed Abstract | Publisher Full Text

28. Slamova L, Starkova J, Fronkova E, et al:: CD2-positive B-cell precursor acute lymphoblastic leukemia with an early switch to the monocytic lineage. Leukemia. 2014; 28(3): 609-20.

PubMed Abstract | Publisher Full Text

29. Gu Z, Churchman M, Roberts K, et al:: Genomic analyses identify recurrent
MEF2D fusions in acute lymphoblastic leukaemia. Nat Commun. 2016; 7: 13331. PubMed Abstract | Publisher Full Text | Free Full Text

30. F Hirabayashi S, Ohki K, Nakabayashi K, et al:: ZNF384-related fusion genes define a subgroup of childhood B-cell precursor acute lymphoblastic leukemia with a characteristic immunotype. Haematologica. 2017; 102(1): 118-29. PubMed Abstract | Publisher Full Text | Free Full Text | F1000 Recommendation

31. F McClure BJ, Heatley SL, Kok CH, et al.: Pre-B acute lymphoblastic leukaemia recurrent fusion, EP300-ZNF384, is associated with a distinct gene expression. Br J Cancer. 2018; 118(7): 1000-4.

PubMed Abstract | Publisher Full Text | Free Full Text | F1000 Recommendation

32. Gocho $\mathrm{Y}$, Kiyokawa N, Ichikawa $\mathrm{H}$, et al:: A novel recurrent EP300-ZNF384 gene fusion in B-cell precursor acute lymphoblastic leukemia. Leukemia. 2015; 29(12): 2445-8. PubMed Abstract | Publisher Full Text

33. Hrusak O, de Haas V, Stancikova J, et al:: International cooperative study identifies treatment strategy in childhood ambiguous lineage leukemia. Blood. 2018; 132(3): 264-76.

PubMed Abstract | Publisher Full Text

34. $\mathrm{F}$ Shago M, Abla O, Hitzler J, et al.: Frequency and outcome of pediatric acute lymphoblastic leukemia with ZNF384 gene rearrangements including a novel translocation resulting in an ARID1B/ZNF384 gene fusion. Pediatr Blood Cancer. 2016; 63(11): 1915-21.

PubMed Abstract | Publisher Full Text | F1000 Recommendation

35. Herglotz J, Unrau L, Hauschildt F, et al.: Essential control of early B-cell development by Mef2 transcription factors. Blood. 2016; 127(5): 572-81 PubMed Abstract | Publisher Full Text

36. F Suzuki K, Okuno Y, Kawashima N, et al:: MEF2D-BCL9 Fusion Gene Is Associated With High-Risk Acute B-Cell Precursor Lymphoblastic Leukemia in Adolescents. J Clin Oncol. 2016; 34(28): 3451-9.

PubMed Abstract | Publisher Full Text | F1000 Recommendation

37. Harewood L, Robinson H, Harris R, et al:: Amplification of AML1 on a duplicated chromosome 21 in acute lymphoblastic leukemia: a study of 20 cases. Leukemia. 2003; 17(3): 547-53.

PubMed Abstract | Publisher Full Text

38. Slater R, Smit E, Kroes W, et al:: A non-random chromosome abnormality found in precursor-B lineage acute lymphoblastic leukaemia: dic(9;20)(p1?3;q11). Leukemia. 1995; 9(10): 1613-9.

PubMed Abstract

39. F Russell LJ, Enshaei A, Jones L, et al:: IGH@ translocations are prevalent in teenagers and young adults with acute lymphoblastic leukemia and are associated with a poor outcome. J Clin Oncol. 2014; 32(14): 1453-62. PubMed Abstract | Publisher Full Text | F1000 Recommendation

40. Hunger SP, Ohyashiki K, Toyama K, et al.: Hlf, a novel hepatic bZIP protein, shows altered DNA-binding properties following fusion to E2A in $t(17 ; 19)$ acute lymphoblastic leukemia. Genes Dev. 1992; 6(9): 1608-20. PubMed Abstract | Publisher Full Text

41. Mullighan CG, Collins-Underwood JR, Phillips LA, et al:: Rearrangement of CRLF2 in B-progenitor- and Down syndrome-associated acute lymphoblastic leukemia. Nat Genet. 2009; 41(11): 1243-6. PubMed Abstract | Publisher Full Text | Free Full Text

42. F Russell LJ, Capasso M, Vater I, et al.: Deregulated expression of cytokine receptor gene, CRLF2, is involved in lymphoid transformation in B-cell precursor acute lymphoblastic leukemia. Blood. 2009; 114(13): 2688-98. PubMed Abstract | Publisher Full Text | F1000 Recommendation

43. F Mullighan CG, Goorha S, Radtke I, et al:: Genome-wide analysis of genetic alterations in acute lymphoblastic leukaemia. Nature. 2007: 446(7137): 758-64. PubMed Abstract | Publisher Full Text | F1000 Recommendation

44. Rand V, Parker H, Russell LJ, et al:: Genomic characterization implicates IAMP21 as a likely primary genetic event in childhood B-cell precursor acute lymphoblastic leukemia. Blood. 2011; 117(25): 6848-55. PubMed Abstract | Publisher Full Text

45. Hunger SP, Mullighan CG: Redefining ALL classification: toward detecting highrisk ALL and implementing precision medicine. Blood. 2015; 125(26): 3977-87. PubMed Abstract | Publisher Full Text | Free Full Text

46. Morak M, Attarbaschi A, Fischer S, et al.: Small sizes and indolent evolutionary dynamics challenge the potential role of P2RY8-CRLF2-harboring clones as main relapse-driving force in childhood ALL. Blood. 2012; 120(26): 5134-42. PubMed Abstract | Publisher Full Text | Free Full Text

47. Ensor HM, Schwab C, Russell LJ, et al.: Demographic, clinical, and outcome features of children with acute lymphoblastic leukemia and CRLF2 deregulation: results from the MRC ALL97 clinical trial. Blood. 2011; 117(7): 2129-36. PubMed Abstract | Publisher Full Text

48. Jain N, Lu X, Daver N, et al.: Co-occurrence of CRLF2-rearranged and Ph+ acute lymphoblastic leukemia: a report of four patients. Haematologica. 2017; 102(12): e514-e517.

PubMed Abstract | Publisher Full Text | Free Full Text

49. Heerema NA, Carroll AJ, Devidas M, et al:: Intrachromosomal amplification of chromosome 21 is associated with inferior outcomes in children with acute lymphoblastic leukemia treated in contemporary standard-risk children's oncology group studies: a report from the children's oncology group. J Clin 
Oncol. 2013; 31(27): 3397-402

PubMed Abstract | Publisher Full Text | Free Full Text

50. Moorman AV, Robinson $\mathrm{H}$, Schwab C, et al.: Risk-directed treatment intensification significantly reduces the risk of relapse among children and adolescents with acute lymphoblastic leukemia and intrachromosomal amplification of chromosome 21: a comparison of the MRC ALL97/99 and UKALL2003 trials. J Clin Oncol. 2013; 31(27): 3389-96.

PubMed Abstract | Publisher Full Text

51. Fischer U, Forster M, Rinaldi A, et al:: Genomics and drug profiling of fatal TCF3-HLF-positive acute lymphoblastic leukemia identifies recurrent mutation patterns and therapeutic options. Nat Genet. 2015; 47(9): 1020-9. PubMed Abstract | Publisher Full Text | Free Full Text

52. Schwab C, Nebral K, Chilton L, et al.: Intragenic amplification of PAX5: a novel subgroup in B-cell precursor acute lymphoblastic leukemia? Blood Adv. 2017; 1(19): 1473-7.

PubMed Abstract | Publisher Full Text | Free Full Text

53. Boer JM, den Boer ML: BCR-ABL1-like acute lymphoblastic leukaemia: From bench to bedside. Eur J Cancer. 2017; 82: 203-18. PubMed Abstract | Publisher Full Text

54. F Yoda A, Yoda Y, Chiaretti S, et al:: Functional screening identifies CRLF2 in precursor B-cell acute lymphoblastic leukemia. Proc Natl Acad Sci U S A. 2010; 107(1): 252-7.

PubMed Abstract | Publisher Full Text | Free Full Text | F1000 Recommendation

55. Hertzberg L, Vendramini E, Ganmore I, et al:: Down syndrome acute lymphoblastic leukemia, a highly heterogeneous disease in which aberran expression of CRLF2 is associated with mutated JAK2: a report from the International BFM Study Group. Blood. 2010; 115(5): 1006-17. PubMed Abstract | Publisher Full Text

56. Bugarin C, Sarno J, Palmi C, et al.: Fine tuning of surface CRLF2 expression and its associated signaling profile in childhood B-cell precursor acute lymphoblastic leukemia. Haematologica. 2015; 100(6): e229-32. PubMed Abstract | Publisher Full Text | Free Full Text

57. F Biondi A, Schrappe M, De Lorenzo $\mathrm{P}$, et al:: Imatinib after induction for treatment of children and adolescents with Philadelphia-chromosomepositive acute lymphoblastic leukaemia (EsPhALL): a randomised, open-label, intergroup study. Lancet Oncol. 2012; 13(9): 936-45. PubMed Abstract | Publisher Full Text | Free Full Text | F1000 Recommendation

58. $\mathrm{F}$ Andersson $\mathrm{AK}, \mathrm{Ma} \mathrm{J}$, Wang J, et al.: The landscape of somatic mutations in infant MLL-rearranged acute lymphoblastic leukemias. Nat Genet. 2015; 47(4): 330-7.

PubMed Abstract | Publisher Full Text | Free Full Text | F1000 Recommendation

59. F Holmfeldt L, Wei L, Diaz-Flores E, et al:: The genomic landscape of hypodiploid acute lymphoblastic leukemia. Nat Genet. 2013; 45(3): 242-52. PubMed Abstract | Publisher Full Text | Free Full Text | F1000 Recommendation

60. F Paulsson K, Lilljebjörn H, Biloglav A, et al:: The genomic landscape of high hyperdiploid childhood acute lymphoblastic leukemia. Nat Genet. 2015; 47(6): $672-6$.

PubMed Abstract | Publisher Full Text | F1000 Recommendation

61. Zhang J, Mullighan CG, Harvey RC, et al:: Key pathways are frequently mutated in high-risk childhood acute lymphoblastic leukemia: a report from the Children's Oncology Group. Blood. 2011; 118(11): 3080-7.

PubMed Abstract | Publisher Full Text | Free Full Text

62. Zaliova M, Hovorkova L, Vaskova M, et al.: Slower early response to treatment and distinct expression profile of childhood high hyperdiploid acute lymphoblastic leukaemia with DNA index $<1.16$. Genes Chromosomes Cancer 2016; 55(9): 727-37.

PubMed Abstract | Publisher Full Text

63. F Irving J, Matheson E, Minto L, et al:: Ras pathway mutations are prevalent in relapsed childhood acute lymphoblastic leukemia and confer sensitivity to MEK inhibition. Blood. 2014; 124(23): 3420-30. PubMed Abstract | Publisher Full Text | Free Full Text | F1000 Recommendation

64. F Jerchel IS, Hoogkamer AQ, Ariës IM, et al:: RAS pathway mutations as a predictive biomarker for treatment adaptation in pediatric $B$-cell precursor acute lymphoblastic leukemia. Leukemia. 2018; 32(4): 931-40. PubMed Abstract | Publisher Full Text | Free Full Text | F1000 Recommendation

65. Duployez N, Grzych G, Ducourneau B, et al:: NUP214-ABL1 fusion defines a rare subtype of $B$-cell precursor acute lymphoblastic leukemia that could benefit from tyrosine kinase inhibitors. Haematologica. 2016; 101(4): e133-4. PubMed Abstract | Publisher Full Text | Free Full Text

66. Kobayashi K, Miyagawa N, Mitsui K, et al.: TKI dasatinib monotherapy for a patient with Ph-like ALL bearing ATF7IP/PDGFRB translocation. Pediatr Blood Cancer. 2015; 62(6): 1058-60.

PubMed Abstract | Publisher Full Text

67. Lengline $\mathrm{E}$, Beldjord $\mathrm{K}$, Dombret $\mathrm{H}$, et al:: Successful tyrosine kinase inhibitor therapy in a refractory $B$-cell precursor acute lymphoblastic leukemia with EBF1-PDGFRB fusion. Haematologica. 2013; 98(11): e146-8. PubMed Abstract | Publisher Full Text | Free Full Text

68. Masuzawa A, Kiyotani C, Osumi T, et al:: Poor responses to tyrosine kinase inhibitors in a child with precursor B-cell acute lymphoblastic leukemia with SNX2-ABL1 chimeric transcript. Eur J Haematol. 2014; 92(3): 263-7. PubMed Abstract | Publisher Full Text
69. Mayfield JR, Czuchlewski DR, Gale JM, et al.: Integration of ruxolitinib into dose-intensified therapy targeted against a novel JAK2 F694L mutation in B-precursor acute lymphoblastic leukemia. Pediatr Blood Cancer. 2017; 64(5): e26328.

PubMed Abstract | Publisher Full Text | Free Full Text

70. Perwein $\mathrm{T}$, Strehl S, König M, et al:: Imatinib-induced long-term remission in a relapsed RCSD1-ABL1-positive acute lymphoblastic leukemia. Haematologica. 2016; 101(8): e332-5.

PubMed Abstract | Publisher Full Text | Free Full Text

71. F Schwab C, Ryan SL, Chilton L, et al:: EBF1-PDGFRB fusion in pediatric $B$-cell precursor acute lymphoblastic leukemia (BCP-ALL): genetic profile and clinical implications. Blood. 2016; 127(18): 2214-8.

PubMed Abstract | Publisher Full Text | F1000 Recommendation

72. Weston BW, Hayden MA, Roberts KG, et al.: Tyrosine kinase inhibitor therapy induces remission in a patient with refractory EBF1-PDGFRB-positive acute lymphoblastic leukemia. J Clin Oncol. 2013; 31(25): e413-6. PubMed Abstract | Publisher Full Text

73. Ding YY, Stern JW, Jubelirer TF, et al.: Clinical efficacy of ruxolitinib and chemotherapy in a child with Philadelphia chromosome-like acute lymphoblastic leukemia with GOLGA5-JAK2 fusion and induction failure. Haematologica. 2018; 103(9): e427-e431. PubMed Abstract | Publisher Full Text | Free Full Text

74. Malone A, Langabeer S, O'Marcaigh A, et al.: A doctor(s) dilemma: ETV6-ABL1 positive acute lymphoblastic leukaemia. Br J Haematol. 2010; 151(1): 101-2. PubMed Abstract | Publisher Full Text

75. Yeung DT, Moulton DJ, Heatley SL, et al.: Relapse of BCR-ABL1-like ALL mediated by the $A B L 1$ kinase domain mutation T315I following initial response to dasatinib treatment. Leukemia. 2015; 29(1): 230-2.

PubMed Abstract | Publisher Full Text

76. Zhang $\mathrm{Y}, \mathrm{Gao} \mathrm{Y}$, Zhang $\mathrm{H}$, et al.: PDGFRB mutation and tyrosine kinase inhibitor resistance in Ph-like acute lymphoblastic leukemia. Blood. 2018; 131(20): 2256-61.

PubMed Abstract | Publisher Full Text | Free Full Text

77. Slayton WB, Schultz KR, Kairalla JA, et al:: Dasatinib Plus Intensive Chemotherapy in Children, Adolescents, and Young Adults With Philadelphia Chromosome-Positive Acute Lymphoblastic Leukemia: Results of Children's Oncology Group Trial AALL0622. J Clin Oncol. 2018; 36(22): 2306-14. PubMed Abstract | Publisher Full Text | Free Full Text

78. Lukes J Jr, Potuckova E, Sramkova L, et al: Two novel fusion genes, AIF1L-ETV6 and ABL1-AIF1L, result together with ETV6-ABL1 from a single chromosomal rearrangement in acute lymphoblastic leukemia with prenatal origin. Genes Chromosomes Cancer. 2018; 57(9): 471-7.

PubMed Abstract | Publisher Full Text

79. Zimmermannova O, Doktorova E, Stuchly J, et al:: An activating mutation of GNB1 is associated with resistance to tyrosine kinase inhibitors in ETV6-ABL1 positive leukemia. Oncogene. 2017; 36(43): 5985-94. PubMed Abstract | Publisher Full Text | Free Full Text

80. Zuna J, Zaliova M, Muzikova K, et al.: Acute leukemias with ETV6/ABL1 (TEL/ $A B L)$ fusion: poor prognosis and prenatal origin. Genes Chromosomes Cancer. 2010; 49(10): 873-84. PubMed Abstract | Publisher Full Text

81. Schwartzman O, Savino AM, Gombert M, et al:: Suppressors and activators of JAK-STAT signaling at diagnosis and relapse of acute lymphoblastic leukemia in Down syndrome. Proc Natl Acad Sci U S A. 2017; 114(20): E4030-E4039. PubMed Abstract | Publisher Full Text | Free Full Text

82. F Clappier E, Grardel N, Bakkus M, et al:: IKZF1 deletion is an independent prognostic marker in childhood B-cell precursor acute lymphoblastic leukemia, and distinguishes patients benefiting from pulses during maintenance therapy: results of the EORTC Children's Leukemia Group study 58951. Leukemia. 2015; 29(11): 2154-61. PubMed Abstract | Publisher Full Text | F1000 Recommendation

83. van der Veer A, Zaliova M, Mottadelli F, et al.: IKZF1 status as a prognostic feature in BCR-ABL1-positive childhood ALL. Blood. 2014; 123(11): 1691-8. PubMed Abstract | Publisher Full Text

84. Asai D, Imamura T, Suenobu S, et al.: IKZF1 deletion is associated with a poor outcome in pediatric B-cell precursor acute lymphoblastic leukemia in Japan. Cancer Med. 2013; 2(3): 412-9.

PubMed Abstract | Publisher Full Text | Free Full Text

85. Chen IM, Harvey RC, Mullighan CG, et al:: Outcome modeling with CRLF2, IKZF1, $J A K$, and minimal residual disease in pediatric acute lymphoblastic leukemia: Children's Oncology Group study. Blood. 2012; 119(15): 3512-22. PubMed Abstract | Publisher Full Text | Free Full Text

86. Dörge $\mathrm{P}$, Meissner B, Zimmermann M, et al.: IKZF1 deletion is an independent predictor of outcome in pediatric acute lymphoblastic leukemia treated according to the ALL-BFM 2000 protocol. Haematologica. 2013; 98(3): 428-32. PubMed Abstract | Publisher Full Text | Free Full Text

87. F Kuiper RP, Waanders E, van der Velden VH, et al.: IKZF1 deletions predict relapse in uniformly treated pediatric precursor B-ALL. Leukemia. 2010; 24(7): 1258-64.

PubMed Abstract | Publisher Full Text | F1000 Recommendation

88. Olsson L, Castor A, Behrendtz M, et al.: Deletions of IKZF1 and SPRED1 are associated with poor prognosis in a population-based series of pediatric 
B-cell precursor acute lymphoblastic leukemia diagnosed between 1992 and 2011. Leukemia. 2014; 28(2): 302-10.

PubMed Abstract | Publisher Full Text

89. Olsson L, Ivanov Öfverholm I, Norén-Nyström U, et al.: The clinical impact of IKZF1 deletions in paediatric B-cell precursor acute lymphoblastic leukaemia is independent of minimal residual disease stratification in Nordic Society for Paediatric Haematology and Oncology treatment protocols used between 1992 and 2013. Br J Haematol. 2015; 170(6): 847-58.

PubMed Abstract | Publisher Full Text

90. $\mathrm{F}$ van der Veer A, Waanders E, Pieters $\mathrm{R}$, et al.: Independent prognostic value of BCR-ABL1-like signature and IKZF1 deletion, but not high CRLF2 expression, in children with B-cell precursor ALL. Blood. 2013; 122(15): 2622-9. PubMed Abstract | Publisher Full Text | Free Full Text | F1000 Recommendation
91. Yamashita Y, Shimada A, Yamada T, et al.: IKZF1 and CRLF2 gene alterations correlate with poor prognosis in Japanese BCR-ABL1-negative high-risk B-cell precursor acute lymphoblastic leukemia. Pediatr Blood Cancer. 2013; 60(10): 1587-92.

PubMed Abstract | Publisher Full Text

92. Yang YL, Hung CC, Chen JS, et al:: IKZF1 deletions predict a poor prognosis in children with B-cell progenitor acute lymphoblastic leukemia: a multicenter analysis in Taiwan. Cancer Sci. 2011; 102(10): 1874-81. PubMed Abstract | Publisher Full Text

93. Stanulla M, Dagdan E, Zaliova M, et al.: IKZF1 plus Defines a New Minimal Residual Disease-Dependent Very-Poor Prognostic Profile in Pediatric B-Cell Precursor Acute Lymphoblastic Leukemia. J Clin Oncol. 2018; 36(12): 1240-9. PubMed Abstract | Publisher Full Text 


\section{Open Peer Review}

\section{Current Peer Review Status:}

\section{Editorial Note on the Review Process}

Faculty Reviews are review articles written by the prestigious Members of Faculty Opinions. The articles are commissioned and peer reviewed before publication to ensure that the final, published version is comprehensive and accessible. The reviewers who approved the final version are listed with their names and affiliations.

\section{The reviewers who approved this article are:}

\section{Version 1}

\section{Stuart S. Winter}

Pediatric Hematology-Oncology, Children's Minnesota Research Institute, , Minneapolis, Minnesota, USA

Competing Interests: No competing interests were disclosed.

\section{Ching-Hon Pui}

Departments of Oncology and Pathology, Hematological Malignancies Program, St. Jude Children's Research Hospital, and College of Medicine, University of Tennessee Health Science Center, Memphis, TN, USA

Competing Interests: No competing interests were disclosed.

\section{Nobutaka Kiyokawa}

Department of Pediatric Hematology and Oncology Research, National Research Institute for Child Health and Development, Tokyo, Japan

Competing Interests: No competing interests were disclosed. 
The benefits of publishing with F1000Research:

- Your article is published within days, with no editorial bias

- You can publish traditional articles, null/negative results, case reports, data notes and more

- The peer review process is transparent and collaborative

- Your article is indexed in PubMed after passing peer review

- Dedicated customer support at every stage

For pre-submission enquiries, contact research@f1000.com 